\title{
EFEKTIFITAS PENDEKATAN KETELADANAN DALAM PEMBINAAN AKHLAK SISWA DI MIN BANDAR GADANG
}

\author{
Iswandi \\ wandii291@gmail.com \\ STAI YAPTIP Pasaman Barat
}

\begin{abstract}
The purpose of this reseach is to examine what kind of approach that is given by teachers in fostering the MIN morals of students in Bandar Gadang and find out the constraints and convenience faced by the teacher in building the mor of MIN students in Bandar Gadang. In this paper the authors use field research (Field Research) using qualitative methods to gather information by revealing data and describing events, phenomena that occur in the field as they are. To get the data in this study the authors used techniques, interviews, and observations to teachers at MIN Bandar Gadang. The results of this study illustrate the efforts that have been made by teachers in fostering student morals at MIN Bandar Gadang not only with regard to manners, social procedures, ways of behaving and ways to behave in my daily life. But more deeply, the teacher's example is also seen in the spiritual formation of students through filling their hearts and spirituality with the qualities of patience, responsibility, fairness, honesty, forgiveness and all of these qualities must be reflected in the teacher's personality. The driving factor in fostering student morals is religious understanding students have started to go deep, because the family also provides motivation and encouragement to students and is supported by religious facilities in the school environment, so that the inculcation of moral values to them is easier.
\end{abstract}

Keywords: Exemplary, Morals

\begin{abstract}
Abstrak
Tujuan dari penelitian ini adalah untuk mengkaji pendekatan seperti apa yang diberikan guru dalam membina Akhlak siswa MIN di Bandar Gadang dan mengetahui kendala dan kemudahan yang dihadapi oleh guru dalam pembinan akhlak siswa MIN di Bandar Gadang. Dalam tulisan ini penulis menggunakan penelitian lapangan (Field Research) dengan menggunakan metode kualitatif untuk menghimpun informasi dengan menggungkap data dan menggambarkan kejadian-kejadian, fenomena yang terjadi di lapangan sebagaimana adanya. Untuk mendapatkan data dalam penelitian ini penulis menggunakan teknik, wawancara, dan observasi kepada guru di MIN Bandar Gadang. Hasil penelitian ini menggambarkan usaha yang telah dilakukan guru dalam pembinaan akhlak siswa di MIN Bandar Gadang tidak hanya berkenaan dengan sopan santun, tata cara pergaulan, tata cara bersikap dan tata cara berpeliku dalam kehidupan seharihari. Akan tetapi lebih mendalam, keteladanan guru juga terlihat dalam pembinaan rohani siswa melalui pengisian hati dan rohaniahnya dengan sifat-sifat sabar, bertanggungjawab, adil, jujur, pemaaf dan kesemua sifat tersebut mesti tercermin dalam pribadi guru.Faktor pendorong dalam pembinaan akhlak siswa adalah pemahaman agama siswa sudah mulai mendalam, disebabkan keluarga ikut memberikan motivasi dan dorongan kepada siswa dan didukung oleh sarana ibadah di lingkungan sekolah, sehingga penanaman nilai-nilai akhlak kepada mereka lebih mudah.
\end{abstract}

Kata Kunci : Keteladanan, Akhlak 


\section{PENDAHULUAN}

Pentingnya dikaji metode keteladanan pendidikan Islam dalam perspektif AlQuran. Karena fenomenanya pendidikan Islam kurang diminati oleh masyarakat. Untuk itu, pendidikan Islam harus dikemas dan direformulasikan pada paradigma ke depan yang mampu menjawab kebutuhan masyarakat dengan memahami Al-Quran secara tekstual dan kontekstual. (Taklimudin, 2018). Keteladanan yang ditanamkan oleh para pendiri bangsa semakin lama semakin menipis, mulai dari memudarnya keteladanan para pemimpin, tokoh masyarakat, orang tua, dan bahkan guru sebagai pengemban utama pendidikan formal di sekolah. (Irfan, 2019). Keberhasilan pendidikan sangat dipengaruhi oleh seluruh faktor yang mendukung pelaksanaan pendidikan itu sendiri dan salah satu faktor yang menentukan keberhasilan pendidikan adalah pendekatan yang digunakan oleh guru dalam memberikan materi pendidikan kepada peserta didik. Di samping itu, Islam juga sangat menganjurkan penganutnya untuk menuntut ilmu pengetahuan. (Iswandi, 2018a). Pada dasarnnya, manusia sangat cenderung memerlukan sosok teladan dan panutan yang mampu mengarahkan manusia pada jalan kebenaran dan cara mengamalkan syari'at Allah swt. (Elsa Aprlianingsih, 2019). Dengan demikian pendidikan sangat perlu karena pendidikan adalah suatu kegiatan atau usaha sadar yang dilakukan secara sadar dan disengaja untuk memberikan bimbingan, baik jasmani maupun rohani, melalui penanaman nilai-nilai Islam, sehingga melahirkan perubahan ke arah positif yang natinya bisa di aplikasikasikan dalam kehidupan, dengan kebiasaan bertingkah laku yang baik, berpikir dan dan berbudi luhur hingga terbentuknya manusia yang berakhlak mulia. (Khairuni \& Khairuni, 2016).

Memasuki milenial yang ditandai dengan perkembangan ilmu pengetahuan dan teknologi, terutama teknologi informasi dan kemunikasi, yang pertama ikut berpengaruh dan mengalami pergeseran adalah nilai-nilai, baik nilai budaya, nilai etika, adat istiadat, maupun nilai agama.(Kabiba, Pahenra, 2017). Oleh karenanya, sebuah pembelajaran sangat ditentukan keberhasilannya oleh kiat masing-masing guru di dalam kelas, sebab tenaga pengajar yang profesional akan terukur dan sejauh mana dia menguasai kelas yang diasuhnya, tapi ada sebagian lain mengantarkan peserta didiknya mencapai hasil belajar yang optimal. Hal ini terlihat bahwa keberhasilan belajar lebih banyak ditentukan oleh seorang guru dalam memberikan pendidikan terutama proses 
pembelajaran di dalam kelas. Keberhasilan guru di dalam kelas juga sangat tergantung kepada pendekatan yang digunakan dalam memberikan materi pendidikan kepada peserta didik. Pendekatan pendidikan dapat dilakukan oleh guru seperti pendekatan pengalaman dengan memberikan pengalaman kepada siswa dalam menanamkan nilainilai keagamaan, pendekatan pembiasaan dengan menanamkan kebiasaan-kebiasaan yang baik kepada siswa, pendekatan emosional untuk memberikan pendekatan perasaan, pendekatan rasional, pendekatan fungsional dan pendekatan keteladan.

Pendekatan keteladanan adalah memperlihatkan keteladanan, baik yang berlangsung melalui penciptaan kondisi pergaulan yang akrab antara personil sekolah, perilaku pendidik dan tenaga pendidik lainnya yang mencerminkan akhlak terpuji, maupun yang tidak langsung melalui suguhan ilustrasi berupa kisah-kisah keteladanan. Dengan keteladanan guru secara langsung mengajarkan pendidikan akhlak kepada peserta didik mana yang baik untuk ditiru maupun juga sebaliknya mana yang tidak pantas untuk ditiru.(Rahmat Rais, Mudzanatun, 2012). Keteladanan pada dasarnya sikap yang dicerminkan oleh seseorang baik disengaja untuk ditiru oleh orang lain maupun prilaku baik yang timbul tanpa sengaja karena sudah menjadi kebiasaan sehingga di tiru oleh anak didik. Jadi dalam mendidik karakter sangat dibutuhkan sosok yang menjadi model. Model yang dapat ditemukan oleh peserta didik di lingkungan sekitarnya. (Nurchaili, 2010).

Keteladan guru terhadap peserta didik merupakan kunci keberhasilannya dalam mempersiapkan dan membentuk moral spiritual dan sosial anak dan Guru jangan hanya berucap saja, memberi nasehat saja pada peserta didik, yang terpenting adalah tindakan nyata guru sehingga dapat dicontoh dan di tiru oleh peserta didik. (Nurchaili, 2010). Hal ini disebabkan karena guru adalah figur terbaik dalam pandangan anak yang akan dijadikannya sebagai teladan dalam mengidentifikasikan diri dalam segala aspek kehidupannya atau figur guru tersebut terpatri dalam jiwa dan perasaannya dan tercermin dalam ucapan dan perbuatannya. Nilai-nilai keteladan yang dapat dilihat oleh para siswa adalah hal-hal yang terlihat oleh pandangan mereka baik dari sikap maupun prilaku para guru baik yang dilakukan secara sadar maupun tidak sadar dari nilai-nilai yang terkandung dalam sikap dan perbuatan guru tersebut. 
Keteladanan dalam pendidikan adalah metode yang paling utama dan yang paling meyakinkan keberhasilannya dalam mempersiapkan dan membentuk moral spiritual dan sosial anak. Hal ini adalah karena pendidik merupakan figur terbaik dalam pandangan anak yang akan ditirunya dalam tindak tanduk, dan tata santunnya, disadari atau tidak bahkan terpatri dalam jiwa dan perasaannya. Gambaran seorang pendidik akan tercermin dalam ucapan dan perbuatan. Keteladanan dapat menentukan apakah guru menjadi pendidik dan pembina yang baik ataukah akan menjadi perusak atau penghancur bagi hari depan anak didik, terutama bagi anak didik yang masih kecil. Guru merupakan faktor pendidikan yang menempati posisi utama dalam memegang peranan penting dalam keseluruhan Proses Pembelajaran di Sekolah. (Saripah, 2016). Kecenderungan manusia untuk belajar lewat peniruan menyebabkan keteladanan menjadi sangat penting artinya dalam proses pendidikan. Pentingnya keteladanan sebagai sarana pendidikan telah diungkapkan dalam Al-Quran surat al-Ahzab ayat 21:

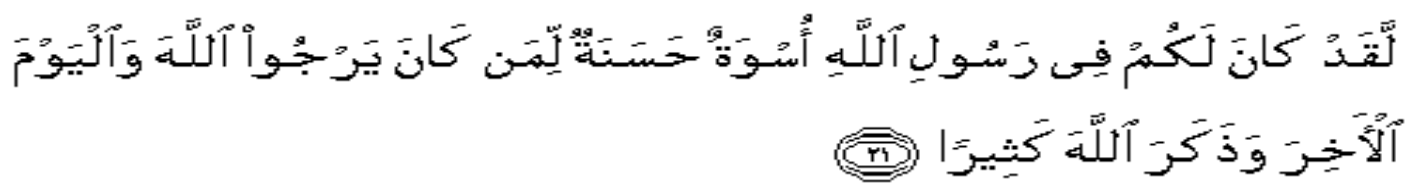

"Sesungguhnya telah ada pada (diri) Rasulullah itu suri teladan yang baik bagimu (yaitu) bagi orang yang mengharap (rahmat) Allah dan (kedatangan) hari kiamat dan dia banyak menyebut Allah".(Departemen Agama RI, 2003)

Dari sini masalah keteladan menjadi faktor penting dalam hal buruknya akhlak anak didik, jika guru jujur, dapat dipercaya, berakhlak mulia, berani, dan menjauhkan diri dari perbuatan yang bertentangan dengan agama, maka anak didik akan tumbuh dalam kejujuran, terbentuk dengan akhlak mulia, keberanian dan dalam sikap yang menjauhkan diri dalam hal yang bertentangan dengan agama. Dalam pendekatan keteladanan ini ada beberapa metode yang dapat digunakan oleh guru diantaranya melalui performance (penampilan), kepribadian, cerita dan ilustrasi yang mengandung unsur keteladanan. Dalam proses pendidikan berarti setiap guru harus menjadi teladan bagi peserta didik, keteladan ini dalam semua kebaikan, dengan keteladanan ini dimaksudkan peserta didik senantiasa akan mencontoh segala sesuatu yang baik-baik dalam perkataan dan perbuatan. 
Berdasarkan observasi dan wawancara penulis pada beberapa orang siswa dan masyarakat disekitar MIN Bandar Gadang bahwa adanya para guru yang ditemukan hanya datang ke sekolah hanya sebatas melakukan kewajibannya sebagai tenaga pengajar. Bahkan ada guru yang tidak memperlihatkan keteladanan kepada siswa, adanya guru yang masih mengeluarkan perkataan yang tidak baik. Apabila hal ini terus berlanjut maka keberhasilan pendidikan di MIN Bandar Gadang terutama pendidikan akhlak tidak akan berhasil secara maksimal. Secara tidak langsung sikap dan prilaku guru akan menjadi pedoman dalam bersikap dan berperilaku bagi siswa. Dan bahkan ada anak guru yang bertindak tidak sesuai dengan etika seorang siswa, sedangkan guru yang lain tidak dapat berbuat untuk menegur karena disebabkan yang berbuat adalah anak guru. Fenomena di atas merupakan suatu indikasi yang menunjukkan bahwa keteladanan guru belum terlihat oleh para siswa. Berdasarkan uraian di atas, maka penulis merasa tertarik untuk mengkaji dan melihat lebih jauh dengan melakukan penelitian ini yang berjudul "Pendekatan Keteladanan yang diberikan Guru dalam membina Akhlak Siswa di Bandar Gadang”.

\section{METODE PENELITIAN}

Dalam kajian tulisan ini penulis menggunakan metode kualitatif, menurut Bogdan dan Taylor metode kualitatif menghasilkan data deskriptif berupa kata-kata tertulis atau lisan dari orang-orang dan prilaku yang diamati. Metode deskriptif merupakan data yang dikumpulkan berupa kata-kata, gambar, dan bukan angka-angka serta data tersebut juga berasal dari naskah wawancara, catatan dilapangan, foto, dokumentasi pribadi dan dokumentasi resmi lainnya. Metode deskriptif digunakan untuk menghimpun data dengan menggungkapkan data dan menggambarkan kejadiankejadian, fenomena yang terjadi di lapangan dengan sebagaimana adanya. Dalam penelitian pendekatan keteladan yang diberikan oleh guru dalam membina akhlak siswa MIN Bandar Gadang. Yang penulis lakukan adalah untuk mengumpulkan data dan fakta yang berhubungan dengan permasalahan penelitian. Dengan demikian, metode deskriptif ini lebih memungkinkan bagi penulis untuk memperoleh dan mengumpulkan data dan fakta sebenarnya tentang pendekatan keteladan yang diberikan oleh guru dalam membina akhlak siswa MIN Bandar Gadang. Sumber data adalah tempat memperoleh 
data yang dibutuhkan dalam penelitian baik sumber data primer maupun data sekunder. Sumber data primer yaitu data pokok yang terkait dengan masalah penelitian ini dan yang merupakan data primer adalah guru, siswa MIN Bandar gadang dan masyarakat. Sumber data sekunder merupakan data pendukung dari permasalahan penelitian berupa data dari buku-buku, dokumentasi dan keterangan tertulis yang dapat memberikan informasi.

Sedangkan teknik pengumpulan data dilakukan dengan wawancara, observasi dan dokumentasi. Wawancara adalah pengambilan data atau informasi yang akurat untuk keperluan dalam proses pemecahan masalah tertentu yang sesuai dengan data. Teknik wawancara ini dapat berupa teknik wawancara terstruktur yang pertanyaanpertanyaannya ditetapkan oleh penulis dan wawancara tidak terstruktur untuk mempermudah mendapatkan data dan informasi. Wawancara ini penulis lakukan kepada guru dan siswa MIN Bandar Gadang serta masyarakat di sekitar MIN Bandar Gadang. Observasi merupakan teknik pengumpulan data yang paling lazim dipakai dalam penelitian kualitatif. Fokus perhatian dalam penelitian ini adalah pemahaman dan kemampuan dalam membuat makna atas suatu kejadian atau fenomena pada situasi yang nampak. Tujuan dari pengamatan langsung adalah untuk memperoleh informasi tentang pendekatan keteladan yang diberikan oleh guru dalam membina akhlak siswa MIN Bandar Gadang. Dokumentasi merupakan teknik pengumpulan data yang bersumber dari data-data dokumentasi yang dapat berupa foto-foto maupun tulisan yang dapat mendukung penelitian. Teknik pengolahan data dilakukan setelah setelah penulis melakukan wawancara dan observasi langsung, maka data tersebut diolah atau ditulis dengan cara kualitatif, sesuai dengan penelitian kualitatif, maka data yang didapatkan dianalisis dengan menggunakan metode induktif yaitu mengumpulkan data yang bersifat khusus pendekatan keteladan yang diberikan oleh guru dalam membina akhlak siswa MIN Bandar Gadang, yang kemudian mengarahkannya menjadi pernyataan umum.

\section{Pendekatan Pendidikan Melalui Keteladanan}

Dalam Kamus Besar Bahasa Indonesia pendekatan adalah daya yang ada atau timbul dari sesuatu (orang, benda) yang ikut membentuk watak, kepercayaan atau perbuatan seseorang.(Departemen P \& K, 1988). Sedangkan dalam bahasa Arab, 
keteladanan keteladaan sinonim dengan terma al-qudwah dan al-uswah. al-Qudwah atau al-qidwah secara literal-etimologis (lughatan), berarti sesuatu yang layak untuk diikuti atau diteladani (li mâ yuqtadâ bihi). (Rahendra Maya, 2016). Dengan demikian, pendekatan merupakan daya yang timbul dalam diri seseorang untuk mempengaruhi orang lain dalam rangka pembentukan watak atau karakter seseorang. Dengan kata lain, bahwa pendekatan pendidikan merupakan daya yang timbul dalam rangka pembentukan watak dan kepribadian anak didik menuju kedewasaan. Keteladanan guru di sekolah adalah cara yang paling efektif untuk menumbuhkan kembangkan sikap perilaku yang baik pada peserta didik. (Ratnawati, 2018).

Metode dan pendekatan dalam pembelajaran sangat penting. Sebagaimana diungkapkan oleh Iswandi bahwa metode pendidikan yang tidak efektif akan menjadi penghambat kelancaran proses belajar mengajar sehingga banyak tenaga dan waktu terbuang sia-sia.(Iswandi, 2018b). Dalam proses pembelajaran, sangat diperlukan berbagai pendekatan sehingga tujuan dari pendidikan tersebut dapat tercapai. Diantara pendekatan yang dapat digunakan akan penulis uraikan, diantaranya : Pendekatan individual, Pendekatan kelompok, Pendekatan edukatif, Pendekatan pengalaman, Pendekatan pembiasaan, Pendekatan emosional, Pendekatan rasional, Pendekatan fungsional, Pendekatan keagamaan, dan Pendekatan kebermaknaan. Dengan demikian, guna meningkatkan peranan guru dalam proses belajar mengajar dan hasil belajar siswa, maka guru diharapkan mampu menciptakan lingkungan belajar yang efektif. (Altar, 2014).

Selain pendekatan yang telah penulis uraikan di atas, pendekatan lain yang dapat digunakan oleh guru dalam proses pembelajaran diantaranya :

Pendidikan melalui teladan dalah merupakan salah satu teknik pendidikan yang efektif dan sukses. Allah mengutus Muhammad saw menjadi teladan bagi manusia. Di dalam diri beliau Allah menyusun suatu bentuk sempurna metodologi Islam, suatu bentuk yang hidup dan abadi selama sejarah masih berlangsung. Sebagaimana firman Allah dalam surat Al-Ahzab ayat 21 : 


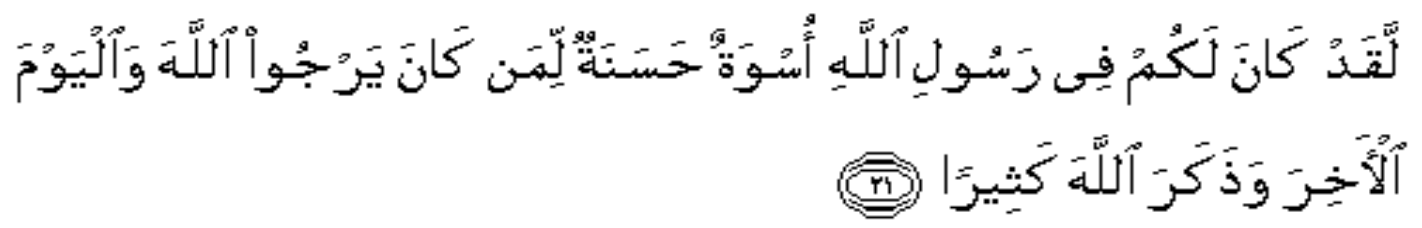

Artinya : "Sesungguhnya telah ada pada (diri) Rasulullah itu suri teladan yang baik bagimu (yaitu) bagi orang yang mengharap (rahmat) Allah dan (kedatangan) hari kiamat dan dia banyak menyebut Allah".(Departemen Agama RI, 2003)

Selanjutnya pendekatan melalui nasehat. Nasehat berpengaruh membuka jalan ke dalam jiwa secara langsung melalui perasaan. Ia menggerakkannya dan menggoncangkan isinya selama waktu tertentu, tak ubahnya seperti orang pemintaminta yang berusaha membangkit-bangkitkan kenistaannya sehingga menyelubungi seluruh dirinya, tetapi bila tidak dibangkit-bangkitkannya maka kenistaanya itu terbenam lagi. Nasihat yang jelas dan dapat dipegangi adalah nasehat yang dapat menggantungkan perasaaan dan tidak membiarkan perasaan itu jatuh ke dasar bawah dan mati tidak bergerak. Dalam Al-Qur'an sendiri penuh berisi nasehat-nasehat dan tuntunan, untuk berbuat kepada sesama manusia. Dengan demikian guru mempunyai tugas untuk bimbingan dan konseling /konselor terkait dengan pengembangan diri siswa yang sesuai dengan kebutuhan, potensi bakat, minat dan kepribadian siswa disekolah. (Putra, 2015).

Dalam proses pembelajaran, guru merupakan orang yang bertangungjawab memberikan nasehat-nasehat kepada siswa, agar tidak terjadi penyimpangan yang dilakukan oleh siswa dan melakukan hal-hal yang di larang dalam ajaran Islam. Dengan demikian nasehat-nasehat yang diberikan oleh guru kepada siswa, dengan sendirinya akan terjalin hubungan emosional dan spiritual antara guru dan siswa. Keteladanan guru dapat dilihat dari prilaku guru sehari-hari baik didalam sekolah maupun di luar sekolah. Selain keteladanan guru, kedisiplinan guru juga menjadi salah satu hal penting yang harus dimiliki oleh guru sebagai seorang pengajar dan pendidik. (Li'ah Haryati, 2016).

Dalam surat Lukman ayat 13 Allah juga memberikan nasehat kepada manusia untuk tidak mempersekutukan Allah dengan sesuatupun. 


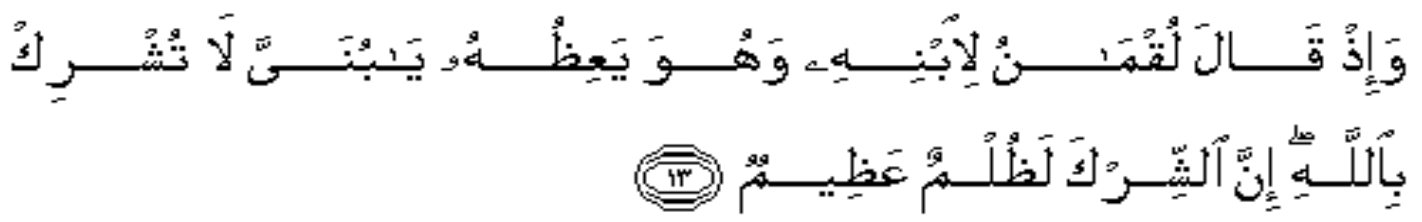

"Dan (ingatlah) ketika Luqman berkata kepada anaknya, di waktu ia memberi pelajaran kepadanya: "Hai anakku, janganlah kamu mempersekutukan Allah, sesungguhnya mempersekutukan (Allah) adalah benar-benar kezaliman yang besar".(Departemen Agama RI, 2003)

Pendekatan melalui hukuman. Hukuman sesungguhnya tidak mutlak diperlukan. Ada orang yang cukup dengan teladan dan nasehat saja, sehingga tidak perlu hukuman baginya. Tetapi manusia tidak sama seluruhnya. Sebagian ada yang dikerasi sekali-kali dengan hukuman. Pendidik (guru) hendaknya menguasai metode ini secara benar agar tidak berimplikasi buruk. Misalnya, seorang pendidik menggunakan kekerasan dalam menegakkan kedisiplinan, sehingga menimbulkan kesalahpahaman yang menjadikan anak trauma dan depresi. (Sujiantari, 2016). Hukuman merupakan alat pendidikan yang apabila akan digunakan harus dipikirkan masak-masak, sebab hukuman belum tentu merupakan alternative yang sangat tepat untuk diberikan kepada anak. Suatu hukuman badan belum tentu menjadi obat yang mujarab untuk membasmi penyakit dan melenyapkannya, tetapi sebaliknya mungkin menyebabkan semakin membesar penyakit dan semakin berlanjutnya kesalahan. Di sisi lain bila guru ingin sukses dalam pengajaran, guru harus memikirkan setiap siswa dan memberikan hukuman yang sesuai setelah guru mempertimbangkan kesalahannya setelah mengetahui latar belakangnya.

Pemberian hukuman yang dilakukan oleh guru dimaksudkan agar siswa tidak melakukan kesalahan yang sama di masa yang akan datang dan upaya untuk menumbuhkan kesadaran siswa untuk tidak mengulanginya. Selain itu dengan hubungan sekolah dan masyarakat yang diberikan mampu membuat siswa jera terhadap tindakan yang telah dilakukan, namun hukuman yang diberikan memiliki nilai-nilai pendidikan. Pada akhirnya timbul kesadaran siswa untuk tidak mengulanginya lagi tanpa danya paksaaan dari orang lain.

Kebiasaan mempunyai peranan penting dalam kehidupan manusia, karena ia menghemat banyak sekali kekuatan manusia, karena sudah menjadi kebiasaan yang sudah melekat dan spontan agar kekuatan itu dapat dipergunakan untuk kegiatan- 
kegiatan di lapangan lain. Tetapi di samping itu kebiasaan juga merupakan faktor penghalang terutama apabila tidak ada penggeraknya dan berubah menjadi kelambanan yang memperlemah dan mengurangi reaksi jiwa. Islam mempergunakan kebiasaan itu sebagai salah satu teknik pendidikan, lalu mengubah seluruh sifat-sifat baik menjadi kebiasaan, dengan pembiasaan itulah diharapkan siswa mengamalkan agamanya secara berkelanjutan. Pendekatan melalui peristiwa-peristiwa. Guru yang baik tidak akan membiarkan peristiwa-peristiwa itu berlalu begitu saja tanpa diambil pengalaman yang berharga. Ia mesti menggunakannya untuk membina dan mendidik jiwa, oleh karena itu pengaruhnya tidak boleh hanya sebentar itu saja.keistimewan peristiwa-peristiwa dari teknik pendidikan adalah bahwa peristiwa-peristiwa itu menimbulkan suatu situasi yang khas didalam perasaan. Suatu peristiwa secara lengkap sangat membekas pada perasaan yang mengirimkan satu jawaban dan reaksi keras yang kadang-kadang dapat meluluhkan perasaan.

\section{Akhlak}

Untuk dapat memahami istilah akhlak secara terpadu dan menyeluruh dapat dilakukan dua langkah yang dapat ditempuh yaitu pengertian akhlak dari segi bahasa (etimologi) dan dari segi istilah (terminologi). Di lihat dari segi bahasa, istilah akhlak berasal dari bahasa Arab yang merupakan bentuk jama' dari kata khuluqun yang mempunyai beberapa arti yaitu tabiat, perangai, adat istiadat, perwira dan agama. (Ali Rajab, 1961) Hamzah Ya'kub mengungkapkan bahwa bahwa kata khuluqun mengandung segi-segi persamaan dengan kata khalqun (kejadian) dan erat hubungannya dengan $\boldsymbol{k h a l i q}$ (pencipta) dan makhluq (yang diciptakan). Oleh karena itu yang dibicarakjan dalam akhlak tidak hanya terbatas pada baik dan buruknya tabiat, perangai dan adat kebiasaan atau perilaku manusia dalam kehidupan sehari-hari.

Kenyataan ini mengindikasikan bahwa masalah akhlak merupakan masalah yang sangat esensial dalam kehidupan manusia sehari-hari. Akan tetapi ayat secara langsung menyebutkan perkataan akhlak/khuluq hanya dua tempat yaitu :

1. Surat al-Qalam ayat 4 :

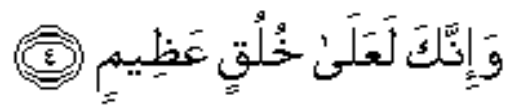

Artinya : "Dan sesungguhnya kamu benar-benar berbudi pekerti yang agung".(Departemen Agama RI, 2003) 


\section{Surat Asy-Syuara' ayat 137}

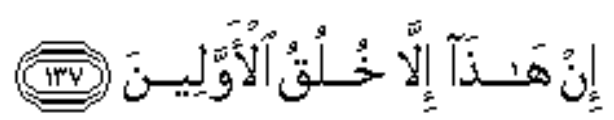

Artinya : "(agama kami) ini tidak lain hanyalah adat kebiasaan orang dahulu". (Departemen Agama RI, 2003)

Pada ayat pertama kata khuluq disebut dalam hubungannya dengan sifat dan prilaku yang baik dan terpuji yaitu pujian terhadap Nabi Muhammad SAW karena beliau memiliki akhlak yang sangat mulia. Akhlak rasulullah tersebut diharapkan dapat dipakai sebagai contoh oleh manusia dalam kehidupan sehari-hari, agar mereka dapat memperoleh kebahagiaan dan kesempurnaan dalam hidup di dunia dan akhirat. Sedangkan pada ayat kedua perkataan khuluq disebut dalam hubungannya dengan perilaku salah dan tercela yang dilakukan oleh kaum 'Ad yang menolak ajakan nabi Hud untuk beriman kepada allah dengan cara meninggalkan perbuatan-perbuatan buruk dan tercela (kesombongan dan kemewahan) yang selalu mereka kerjakan dalam kehidupan sehari-harinya.

Pengertian akhlak secara terminologi diungkapkan oleh beberapa orang para ahli, diantaranya : Ahmad Amin menyatakan bahwa akhlak (khuluq) adalah kehendak yang dibiasakan, maksudnya kehendak itu bila membiasakan sesuatu, maka kebiasan itu dinamakan akhlak.(Amin, n.d.) Ibnu Maskawaih memberikan pengertian akhlak (khuluq) adalah keadaan jiwa seseorang yang mendorong untuk melakukan suatu perbuatan tanpa melalui pemikiran dan pertimbangan terlebih dahulu.

Ketiga pengertian akhlak (khuluq) yang dikemukakan oleh para ahli tersebut di atas terlihat berbeda dalam rumusannya, tetapi secara substansial tidak ada pertentangan antara ketiganya. Oleh karena itu, berdasarkan ketiga pengertian tersebut dapat disimpulkan bahwa akhlak adalah keadaan jiwa yang mendorong timbulnya suatu perbuatan dengan mudah karena dibiasakan sehingga tidak memerlukan pertimbangan dan pemikiran terlebih dahulu. Ukuran akhlak itu bukan dari segi lahiriah saja, tetapi yang lebih penting adalah dari segi batiniah, yakni dorongan hati. Hal ini tentunya sama dengan tujuan pendidikan tingkat satuan pendidikan adalah meletakkan dasar kecerdasan, penge- tahuan, kepribadian, akhlak mul ia, serta keterampilan untuk hidup mandiri dan mengikuti pendidikan lebih lanjut. (Sabar Budi Raharjo, 2010). Dengan demikian akhlak merupakan salah satu dari ajaran Islam yang harus dimiliki oleh setiap 
individu muslim dalam menunaikan kehidupanya sehari-hari. (Suryadarma \& Haq, 2015). Di samping itu pendidikan adalah serangkaian upaya yang dilakukan pendidik untuk membantu membentuk watak, budi pekerti, akhlak dan kepribadian peserta didik. Berdasarkan hal ini, maka pendidikan tidak sekedar mentransfer ilmu kepada peserta didik, tetapi juga membantu peserta didik agar mampu mengembangkan seluruh potensi yang dibawanya secara maksimal. Pendapat ini sejalan dengan pendapat dari sejumlah pakar pada umumnya. (Salik, 2015).

Peran guru dan peserta didik yang dimaksud di sini adalah berkaitan dengan peran dalam proses pembelajaran. Guru dan peserta didik merupakan faktor penentu yang sangat dominan dalam pendidikan umumnya, karena guru dan peserta didik memegang peranan dalam proses pembelajaran, di mana proses pembelajaran merupakan inti dari proses pendidikan secara keseluruhan yang bertujuan terjadinya perubahan tingkah laku anak. (Kirom, 2017). Dalam dunia pendidikan siswa merupakan komponen yang tidak dapat dipisahkan, karena tanpa siswa maka peranan guru dalam dunia pendidikan tidak ada artinya. Siswa merupakan suatu organisme yang selalu mengalami perubahan baik jasmani maupun rohani secara terus menerus dalam usaha menyesuaikan diri dengan lingkungannya. Pada dasarnya siswa merupakan insan yang memiliki fitrah yang perlu dikembangkan sejak usia dini, sebab semua ini akan membawa pengaruh dalam pertumbuhan pada masa selanjutnya.

Fitrah manusia sebagai anugerah Allah SWT yang tidak ternilai harganya harus dkembangkan agar manusia dapat menjadi manusia yang sempurna dan pengembangan fitrah anak didik harus dilakukan secara sadar dan berimbang, apabila tidak dilaksanakan secara berimbang maka tidak akan mencapai manusia yang sempurna dan bahkan dapat mendatangkan kehancuran bagi manusia. Yang perlu pengembangan fitrah manusia melalui pendidikan adalah fitrah agama dan fitrah intelektualnya, sebab apabila fitrah agamanya tidak dikembangkan, manusia akan menjadi mahkluk yang paling jahat dan begitu juga sebaliknya apabila intelektualnya tidak dikembangkan maka akan menjadi mahkluk yang paling bodoh.

Pengembangkan fitrah anak didik adalah melalui proses pembelajaran, sebab pembelajaran merupakan usaha yang dilakukan oleh seorang guru dalam mentranferkan ilmu pengetahuan kepada anak didik. Sehingga potensi yang dimiliki dapat berkembang 
sesuai dengan tuntunan agama dan anak menjadi manusia yang sempurna.ada tiga macam fitrah manusia yang harus dikembangkan melalui pendidikan yaitu fitrah beragama, fitrah intelektual dan fitrah sosial.(Ramayulis, 2002). Sebuah pembelajaran sangat ditentukan keberhasilannya oleh kiat masing-masing guru di dalam kelas, sebab tenaga pengajar yang profesional akan terukur dan sejauh mana dia menguasai kelas yang disauhnya, sehingga mengantarkan peserta didiknya mencapai hasil belajar yang optimal. Hal ini trerlihat bahwa keberhasilan belajar lebih banyak ditentukan oleh seorang guru dalam memberikan pendidikan dalam proses pembelajaran di dalam kelas. Seorang guru selain sebagai orang yang berperan dalam proses transpormasi pengetahuan dan keterampilan, akan tetapi juga berperan memandu segenap proses pembelajaran kepada anak didik termasuk pendidikan akhlak anak didik. Begitu besarnya peranan guru dalam pengembangan fitrah keagamaan anak didik dalam bidang akhlak diharapkan anak didik mampu meninternaslisasikan nilai-nilai ajaran Islam dalam kehidupannya sehari-hari. Seperti akhlak kepada Allah, Rasulullah, orang tua, sesama manusia maupun terhadap lingkungan.

\section{PEMBAHASAN DAN HASIL PENELITIAN}

Secara moralistik, pembinaan akhlak merupakan salah satu cara untuk membentuk mental manusia agar memiliki pribadi yang bermoral, berbudi pekerti luhur dan bersusila. Pembinaan akhlak merupakan penuntun bagi umat manusia untuk memiliki mental dan kepribadian sebaik yang ditunjukkan oleh Al-Quran dan Sunnah Rasul. Tujuan pembinaan akhlak adalah untuk menanamkan nilai-nilai akhlakul karimah yang sangat tepat bagi anak agar di dalam perkembangan mentalnya tidak mengalami hambatan dan penyimpangan kearah yang negatif. Media yang dapat digunakan dalam pembinaan akhlak melalui contoh-contoh, latihan-latihan dan praktek nyata yang dilakukan oleh orang tua di dalam kehidupan rumah tangga, dan guru di sekolah. Dewasa ini kerusakan moral diperparah dengan merebaknya fenomena kehidupan yang dapat menumbuh kembangkan sikap dan perilaku yang amoral atau dekadensi nilai-nilai keagamaan. Fenomena ini diperparah dengan adanya sejumlah tayangan televisi yang telah banyak bercerita bersifat tahayul atau kemusyrikan, filmfilm yang berbau porno, krisis ketauladanan. 
Untuk itu, peranan pendidikan akhlak, baik melalui pendidikan di sekolah maupun dalam keluarga sangat penting. Hal ini perlu dilakukan agar anak didik tidak terjerumus kepada hal-hal yang dapat merusak keimanan yang telah ada dalam diri mereka. Pendidikan akhlak di sekolah merupakan sarana bagi siswa dalam meningkatkan pemahaman agama dan nilai-nilai luhur ajaran Islam. Tujuan pembinaan akhlak yang di sekolah adalah untuk menanamkan nilai-nilai agama kepada anak didik agar dalam berkata, bersikap dan bertindak tanduk sesuai dengan ajaran Islam. Sebagaimana yang diungkapkan oleh Suhendri selaku Kepala Sekolah MIN Bandar Gadang bahwa : "Dalam rangka mengantisipasi terjadinya dekadensi moral/akhlak di tengah-tengah masyarakat sangat perlu kita memberikan pembinaan akhlak terhadap siswa. Hal ini dilakukan dalam rangka menanamkan nilai-nilai agama termasuk pendidikan akhlak, agar siswa mampu mengamalkan ajaran Islam sejak usia dini. Apabila semua ini dapat dilakukan oleh anak didik sejak usia dini, maka pengembangan fitrah keagamaan mereka bisa menjadi kebiasaannya dalam kehidupan seharihari”.(Suhendri, n.d.)

Hal senada juga diungkapkan oleh Nur Asma bahwa : "Salah satu program pendidikan di MIN Bandar Gadang adalah pendidikan akhlak dan tujuan dari pendidikan akhlak adalah untuk menanamkan nilai-nilai agama kepada anak didik yang berkenaan dengan sikap dan perbuatan yang sesuai dengan ajaran Islam. Sehingga nilainilai tersebut dapat mereka aktualisasikan dalam kehidupan sehari-hari dan tujuan akhir dari pendidikan akhlak tersebut adalah terbentuknya pribadi muslim yang paripurna".(Asma, n.d.) Berdasarkan wawancara di atas, dapat disimpulkan bahwa pendidikan akhlak telah dilakukan di MIN Bandar Gadang yang bertujuan agar para siswa mampu mengamalkan ajaran Islam terutama nilai-nilai ajaran akhlak baik dalam segi perkataan, sikap maupun tingkah laku. Pembinaan akhlak terhadap siswa menumbuhkan sifat-sifat yang terpuji agar mampu mengaktualisasikan dan mengaplikasikan ajaran Islam dalam berkata, bersikap dan bertindak dalam kehidupannya sehari-hari. Tujuan akhir yang ingin dicapai adalah terbentuknya kepribadian siswa untuk menjadi seorang muslim yang paripurna.

Berdasarkan observasi dan pengamatan penulis bahwa pendidikan akhlak yang diberikan di MIN Bandar Gadang oleh guru bertujuan adalah untuk membentuk 
kepribadian siswa yang memiliki akhlak yang mulia. Hal ini dilakukan guru dengan memberikan motivasi kepada siswa untuk mampu menumbuhkan sifat-sifat yang terpuji, berkata dengan perkataan yang baik, sehingga siswa mampu mengaktualisasikan sifat-sifat tersebut dalam kehidupannya sehari-hari. Guru berusaha memberikan pemahaman kepada siswa akibat yang dapat ditimbulkan orang yang berakhlak mulia dan begitu juga sebaliknya akibat bagi orang yang memiliki akhlak yang buruk.(Penulis, n.d.). Setiap anak memiliki sifat ingin tahu yang sangat besar terhadap sesuatu, sehingga membuat pemikiran dan panca inderanya melihat kepada hal-hal yang nyata. Hal-hal yang nyata tersebut yang dapat menimbulkan rasa keingin tahuan siswa terhadap sesuatu yang pada akhirnya mereka meniru apa yang pernah mereka lihat. Dengan sifat keingintahuan yang begitu tinggi, maka siswa sejak usia dini perlu diperlihatkan sifatsifat terpuji yang akan mereka tiru dan pada akhirnya menjadi kebiasaan bagi mereka. Dalam dunia pendidikan yang akan mereka tiru adalah segala sikap, perkatan dan perbuatan yang dilakukan oleh guru. Guru merupakan figur atau sosok yang sangat ideal bagi mereka untuk ditiru, sehingga perlu memperlihatkan sifat-sifat terpuji yang akan mejadi teladan bagi siswa. Figur atau sosok guru mempunyai peranan yang sangat besar terhadap pembinaan akhlak siswa. Sebagaimana yang diungkapkan oleh Dasril bahwa :

"Dalam pembinaan akhlak terhadap siswa yang perlu pertama kali dilakukan adalah setiap guru mesti memberikan contoh terhadap siswa, karena guru merupakan figur dan sosok yang akan ditiru oleh siswa. Keteladan guru memegang peranan penting dalam menanamkan nilai-nilai akhlak terhadap siswa di sekolah, sebab setiap sikap dan perilaku guru akan menjadi pedoman bagi siswa dalam berkata, bersikap maupun dalam berbuat".(Dasril, n.d.). Dengan demikian keteladanan seorang guru akan mempunyai pengaruh yang sangat besar terhadap pembinaan akhlak siswa, sebab setiap perkataan, sikap dan perbuatan guru akan menjadi tolak ukur bagi siswa dalam bersikap. Walaupun materi akhlak yang diberikan sangat komplit tidak akan berarti apa-apa, apabila sikap guru tidak sesuai dengan ajaran Islam. Maka untuk itu keteladanan guru sangat berperan sekali dalam pembinaan akhlak siswa."

Berdasarkan wawancara di atas, dapat penulis menyimpulkan bahwa keteladanan guru sangat diperlukan sebagai sarana pembinaan akhlak siswa, sebab 
siswa akan mudah menilai dan mengaktualisasikan apa yang menjadi patokan bagi mereka sesuai dengan sikap dan prilaku gurunya. Keteladanan guru terhadap peserta didik meruapakan kunci keberhasilannya dalam mempersiapkan dan membentuk moral spiritual dan sosial anak. Hal ini dikarenakan guru merupakan sosok terbaik dalam pandangan siswa yang akan dijaikannya sebagai teladan dalam mengidentifikasikan diri dalam segala aspek kehidupannya. Sehingga sosok guru akan tetap terpatri dalam hati sanubarinya dan perasaannya dan tercermin dalam perkataan dan perbuatannya.

Hal ini diperkuat oleh pendapat Suhendri bahwa : "Setiap sikap, perkataan dan perbuatan guru akan menjadi sorotan baik oleh siswa maupun bagi masyarakat disekitarnya. Maka untuk itu di MIN Bandar Gadang ini, sangat saya anjurkan setiap guru untuk tetap menjaga perkataan dan sikap dimanapun mereka berada baik di sekolah, keluarga maupun di masyarakat. Sebab guru merupakan sosok dan figur baik bagi siswa maupun bagi masyarakat untuk bersikap dan berbuat”.(Suhendri, n.d.)

Berdasarkan wawancara di atas, keteladanan guru di MIN Bandar Gadang menjadi tolak ukur dalam pelaksanaan pembinaan akhlak siswa. Keteladanan guru terhadap anak didik merupakan kunci keberhasilannya dalam mempersiapkan dan membentuk moral spiritual dan sosial anak. Hal ini karena guru adalah figur terbaik dalam pandangan anak yang akan dijadikannya sebagai teladan dalam mengidentifikasikan diri dalam segala aspek kehidupannya, atau figur guru tersebut terpatri dalam jiwa dan perasaannya dan tercermin dalam ucapan dan perbuatannya. Sebab kecenderungan anak untuk belajar lewat peniruan menyebabkan keteladanan menjadi sangat penting artinya dalam proses pendidikan. Berdasarkan observasi dan pengamatan penulis bahwa upaya yang dilakukan oleh guru dalam memberikan pembinaan akhlak kepada siswa melalui keteladanan di MIN Bandar Gadang dengan memberikan contoh kepada siswa seperti setelah berbaris setiap guru saling bersalaman satu dengan lainnya. Hal ini memberikan gambaran kepada siswa perlunya untuk saling memaafkan dan menghargai orang lain. Guru di MIN Bandar Gadang apabila memerintahkan siswa untuk mengerjakan sesuatu di kelas, menyuruh siswa dengan menggunakan kata-kata yang baik.(Penulis, n.d.)

Di dalam melaksanakan suatu kegiatan termasuk pembinaan akhlak siswa tidaklah semudah membalik telapak tangan, akan tetapi banyak rintangan dan tantangan 
yang dihadapi. Namun semua itu merupakan salah satu jalan untuk menuju ke arah yang lebih baik, sehingga pembinaan akhlak siswa ke depan menjadi lebih baik dan tujuan pembinaan akhlak adalah terbentuknya pribadi muslim yang paripurna dapat terwujud.

Kendala yang dihadapi oleh guru dalam pembinaan akhlak siswa di MIN Bandar Gadang terdiri dari beberapa faktor, diantaranya : Faktor intern merupakan faktor yang berasal dari dalam diri siswa itu sendiri yang mengakibatkan siswa tidak berakhlak yang baik. Faktor dari dalam diri siswa itu dapat berupa rendahnya pemahaman siswa terhadap ajaran Islam, sehingga dalam berbuat dan berkata siswa tersebut tidak mengindahkan aturan-aturan yang ada dalam ajaran Islam. Rendahnya kesadaran iman dan ibadah siswa akan mempengaruhi siswa dalam berbuat dan bersikap dalam kehidupannya sehari-hari. Iman yang ada pada diri siswa merupakan kekuatan yang mendorong siswa tersebut untuk beribadah dengan ikhlas. Iman dan ibadah yang ikhlas akan menjadi kekuatan yang mendorong siswa untuk memiliki budi pekerti yang luhur sekaligus berfungsi sebagai kekuatan yang dapat menjaga dirinya dari akhlak yang buruk dan tercela. Sebagaimana yang diungkapkan oleh Lora Aria Santi bahwa :

"Kendala yang dihadapi oleh guru selama ini dalam pembinaan akhlak siswa di MIN Bandar Gadang diantaranya adalah siswa yang kurangnya dorongan kekuatan yang ada dalam dirinya untuk melakukan perbuatan yang baik. Hal ini bisa jadi kedangkalan iman dan kurangnya pemahamannya terhadap ajaran Islam, selain itu juga karena kurangnya pembiasaan bagi siswa untuk selalu berbuat baik dalam kehidupannya sehari-hari”.(Santi, n.d.)

Hal yang senada juga dikuatkan oleh Ilhaminuri bahwa :

"Tidak semua siswa di MIN Bandar Gadang ini perbuatannya mencerminkan akhlak yang baik, akan tetapi kendala yang dihadapi selama ini dalam pembinaan akhlak diantaranya kurangnya pembiasaan oleh siswa untuk melakukan perbuatan-perbuatan baik. Akhlak siswa bukanlah merupakan sesuatu yang dibawa sejak lahir, namun sesuatu yang perlu dibentuk melalui pembiasaan. Apabila anak yang sudah terbiasa dengan perbuatan baik, anak dengan sendirinya siswa tersebut akan memiliki akhlak dan kepribadian yang baik dan begitu juga sebaliknya".(Ilhaminuri, n.d.)

Berdasarkan wawancara di atas, dapat penulis menyimpulkan bahwa kendala yang dihadapi oleh guru dalam pembinaan akhlak siswa di MIN Bandar Gadang berasal 
dari dalam diri siswa. Hal ini terlihat dari kurangnya kesadaran siswa terhadap pemahaman dan penghayatan tentang ajaran Islam. Apabila siswa memiliki pemahaman dan penghayatan tentang ajaran Islam dan rajin beribadah, dengan sendirinya siswa tersebut akan memiliki akhlak yang baik. Namun sebaliknya siswa-siswa yang masih memiliki kesadaran yang rendah tentang pemahaman dan penghayatan keagamaannya, akan terlihat terhadap sikap dan perilaku sehari-hari baik dalam berkata, bersikap maupun dalam berbuat. Berdasarkan observasi penulis, terlihat bahwa siswa-siswa yang memiliki akhlak yang kurang baik sering meninggalkan ibadah shalat dan kurang mendapatkan perhatian dari orang tuanya. Apabila anak yang sering melaksanakan ibadah shalat dan mendapatkan perhatian dari orang tua seperti memasukkan anaknya lembaga pendidikan keagamaan seperti MDA, lebih banyak memiliki akhlak yang baik dan memiliki sopan santun.(Penulis, n.d.). Faktor ekstren adalah kondisi luar diri seseorang secara langsung atau tidak langsung, disadari atau tidak disadari merupakan unsur yang turut membentuk perbuatan dan kepribadian orang tersebut. Para ahli etika sepakat bahwa lingkungan merupakan salah satu faktor yang sangat dominan dalam proses pembentukan dan perkembangan kepribadian dan tingkah laku seseorang sejak awal pertumbuhannya. Ahmad Amin membagi lingkungan menjadi dua yaitu lingkungan alam kebendaan dan lingkungan pergaulan rohani.

Faktor ekstern merupakan faktor yang mempengaruhi siswa dari luar saat pembinaan akhlak, diantara : Keluarga merupakan kelompok masyarakat terkecil yang terdiri dari bapak, ibu dan anak-anak, keluarga itu terjadi dari pertemuan (perkawinan) laki-laki dan perempuan berdasarkan hukum dan undang-undang perkawinan. Di dalam keluarga inilah lahir anak-anak dan dalam keuarga juga terjadi interaksi pendidikan. Anak mendapatkan pendidikan dan bimbingan untuk pertama kalinya dari kedua orang tuanya. Keluarga inilah tempat meletakkan dasar-dasar kepribadian anak pada usia yang masih muda, karena pada usia ini anak lebih peka terhadap pengaruh dari orang tua dan anggota keluarga lainnya. Dalam memberikan pendidikan terhadap anak, tanggung jawab yang sangat besar dari orang tua adalah pendidikan mental spiritual dan akhlak anak, sebab hal ini sangat penting dalam pengembangan kepribadian anak dan menentukan untuk pendidikan selanjutnya. Islam memandang akhlak sangat penting dalam kehidupan bahkan islam menegaskan ini merupakan misinya yang utama. Islam 
memerintahkan agar orang tua mendidik anak tentang adab dan sopan santun. Pendidikan keluarga merupakan awal pendidikan anak dan mempunyai peranan yang sangat menentukan dalam pertumbuhan dan perkembangan anak pada masa selanjutnya. Yang memegang peranan yang besar dalam pendidikan keluarga adalah orang tua, dikatakan pendidikan pertama karena dalam keluarga inilah anak mendapatkan pendidikan untuk pertama kalinya sebelum ia mendapatkan pendidikan yang lainnya.

Sebagaimana yang diungkapkan oleh Fatri Yanti bahwa : "Salah satu kendala yang dihadapi dalam pembinaan akhlak siswa di MIN Bandar Gadang adalah kurangnya perhatian orang tua terhadap pendidikan akhlak anak di rumah, sehingga pembinaan akhlak yang diberikan di sekolah tanpa adanya bantuan dari orang tua tidak akan berhasil. Banyak diantara orang tua siswa yang kurang memperhatikan sikap dan perilaku anak di rumah, sebab siswa lebih banyak menghabiskan waktu di lingkungan keluarganya dari pada di sekolah".(Fatri Yanti, n.d.) Dengan demikian orang tua siswa merupakan mitra dari sekolah dalam penyelenggaraan pendidikan, tanpa adanya bantuan dari orang tua siswa, maka tujuan dari pembinaan akhlak di sekolah tidak akan tercapai. Kita menginginkan lulusan dari MIN Bandar Gadang adalah siswa-siswa yang memiliki akhlakul karimah. Namun ada diantara orang tua yang kurang memperhatikan dan mengontrol anak di rumah. Sedangkan orang tua juga mempunyai tanggungjawab yang sangat besar terhadap pendidikan akhlak anaknya". Pendidikan di keluarga mempunyai pengaruh yang dalam bagi kehidupan anak kelak dikemudian hari, karena demikian pentingnya peranan orang tua harus benar-benar menyadarinya sehingga mereka dapat memerankannya sebagaimana mestinya. Orang tua mempunyai tanggungjawab yang sangat besar terselenggaranya pendidikan dan bahkan di tangan orang tualah pendidikan anak ini dapat terselenggara.

Sebagaimana firman Allah dalam surat Al-Ahzab ayat 21 :

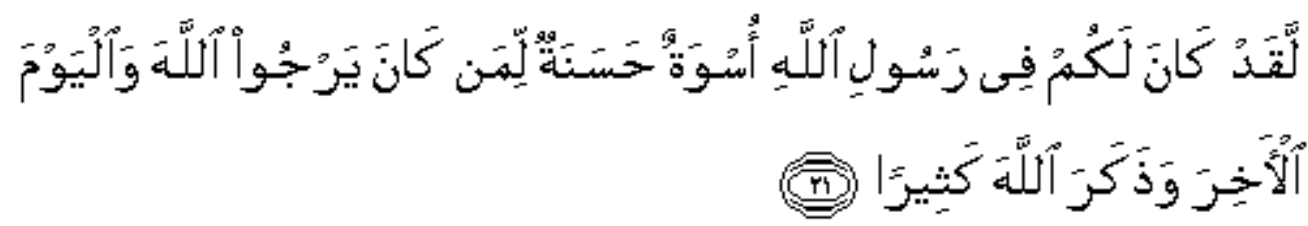

"Sesungguhnya telah ada pada (diri) Rasulullah itu suri teladan yang baik bagimu (yaitu) bagi orang yang mengharap (rahmat) Allah dan (kedatangan) hari kiamat dan dia banyak menyebut Allah"(Departemen Agama RI, 2003) 
Dari ayat di atas dapat diambil kesimpulan bahwa orang tua berkewajiban menyelenggarakan pendidikan untuk anaknya, dengan demikian orang tua memikul tanggungjawab penuh terhadap pendidikan anak. Sekolah hanya menerima limpahan tugas dari orang tua saja, tetapi di luar limpahan tersebut orang tua masih memiliki tanggungjawab yang besar bagi pendidikan anaknya. Dalam memberikan pendidikan terhadap anak, tanggung jawab yang sangat besar dari orang tua adalah pendidikan mental spiritual dan akhlak anak, sebab hal ini sangat penting dalam pengembangan kepribadian anak dan menentukan untuk pendidikan selanjutnya. Islam memandang akhlak sangat penting dalam kehidupan bahkan Islam menegaskan ini merupakan misinya yang utama. Berdasarkan observasi dan pengamatan penulis bahwa pembinaan akhlak siswa di MIN Bandar Gadang kendala yang dihadapi oleh guru adalah faktor lingkungan keluarga. Sebab sadar atau tidak setiap bentuk sikap dan prilaku orang tua diperhatikan oleh anak, terekam dalam memorinya dan kemudian ditiru sesuai dengan perkembangan dan kemampuannya. Walaupun guru di sekolah sudah berusaha memberikan materi pembelajaran akhlak dengan baik, namun belum semuanya didukung dengan pendidikan akhlak dilingkungan keluarga terutama sikap dan perilaku orang tua siswa dan anggota keluarga lainnya. (Penulis, n.d.)

Lingkungan merupakan lingkungan pendidikan yang mempengaruhi perkembangan dan tingkah laku anak, pengaruh yang terlihat jelas ketika anak berada pada lingkungan yang baik dan kondusif, akan membuat perkembangan dan kepribadian anak menjadi baik. Sedangkan bagi anak yang berada pada lingkungan yang kurang kondusif dan kurang baik akan mudah mempengaruhi perkembangan jiwa dan kepribadian anak kepada perbuatan yang kurang baik. Lingkungan yang baik atau positif akan memberikan dorongan dan motivasi serta rangsangan kepada anak untuk menerima, memahami, meyakini dan mengamalkan ajaran Islam. Sedangkan pengaruh lingkungan yang tidak baik tidak akan memberikan motivasi dan dorongan kepada anak untuk meyakini dan mengamalkan ajaran Islam.

Pengaruh lingkungan yang sangat besar tersebut terhadap perkembangan keagamaan dan akhlak siswa, sebab secara tanpa disadari akan mempengaruhi segala perkembangan jiwa dan rohaninya. Dalam upaya pembinaan akhlak siswa di MIN Bandar Gadang, faktor lingkungan merupakan salah satu kendala yang dihadapi oleh 
guru. Sebab setelah anak didik kembali kerumahnya masing-masing, anak-anak akan bergaul dengan orang yang ada disekitarnya dan lingkungannya yang tidak bisa dikendalikan oleh guru. Sebagaimana yang diungkapkan oleh Gusferi Irawan bahwa : "Salah satu kendala yang dihadapi dalam rangka pembinaan akhlak di MIN Bandar Gadang adalah faktor lingkungan, sebab lingkungan dimana siswa berdomisili akan mempengaruhi karakter pribadi dan kejiwaan siswa. Apabila siswa berada di lingkungan yang kurang kondusif, maka dengan sendirinya akan berpengaruh terhadap perkembangan jiwa siswa. Di sekolah guru dapat memantau perkembangan jiwa dan akhlak siswa, namun setelah kembali ke lingkungannya di rumah, maka sikap dan prilakunya kembali seperti biasa di lingkungannya. Lingkungan yang mempengaruhi perkembangan akhlak dan kepribadian siswa pada umumnya adalah lingkungan keluarga dan lingkungan pergaulannya".(Irawan, n.d.). Pendapat di atas juga dikuatkan oleh pendapat yang dikemukakan oleh Dasril bahwa : "Pembinaan akhlak di sekolah tidak akan berhasil apabila siswa tidak mampu mengimbangi dengan kesadaran dalam dirinya untuk memiliki akhlak yang baik. Kadang kala yang membuat siswa itu susah untuk merubah sikapnya dipengaruhi oleh lingkungan terutama lingkungan pergaulan dan lingkungan di sekitar tempat tinggal. Lingkungan keluarga juga mempengaruhi terhadap kepribadian siswa, apabila siswa berada dalam lingkungan keluarga yang penuh kasih sayang, ama akan memiliki kepribadian yang baik. Namun sebaliknya siswa yang tinggal dalam keluarga yang kurang menanamkan nilai-nilai keagamaan, maka siswa tersebut akan memiliki kepribadian yang baik”.(Dasril, n.d.)

Berdasarkan wawancara di atas, dapat dipahami bahwa salah satu faktor yang menjadi kendala dalam pembinaan akhlak siswa adalah faktor lingkungan. Sebab pengaruh lingkungan terhadap perkembangan jiwa dan kepribadian siswa sangat dominan. Siswa dengan akal pikirannya seharusnya tidak begitu saja menyerah kepada lingkungan, baik lingkungan alam maupun lingkungan pergaulan. Siswa harus mampu merubah dan menguasai lingkungan yang ada disekitarnya baik lingkungan alam maupun lingkungan pergaulan. Berdasarkan observasi penulis bahwa kendala yang dihadapi oleh guru di MIN Bandar Gadang dalam pembinaan akhlak siswa adalah faktor lingkungan tempat domisili siswa. Sebab lingkungan siswa sangat berpengaruh dalam pembentukan sikap dan kepribadian siswa, walaupun guru di sekolah telah memberikan berbagai macam materi pelajaran akhlak dan memberikan contoh tauladan kepada siswa. Akan tetapi masih ada siswa yang tidak mampu merubah dan menguasai 
lingkungan disekitarnya, sehingga materi pembelajran akhlak di sekolah yang diberikan oleh guru belum mempnyai pengaruh yang cukup signifikan terhadap perubahan sikap dan perilaku siswa.(Penulis, n.d.)

\section{SIMPULAN DAN SARAN}

Berdasarkan hasil penelitian yang telah penulis kemukakan di atas, dapat penulis menyimpulkan bahwa : Pertama: Usaha yang telah dilakukan oleh guru dalam pembinaan akhlak siswa melalui keteladanan guru di MIN Bandar Gadang tidak hanya berkenaan dengan sopan santun, tata karma pergaulan, tata cara bersikap dan tata cara berpelikau dalam kehidupan sehari-hari. Akan tetapi lebih mendalam, keteladan guru juga menyangkut pembinaan rohaniah siswa melalui opengisian hati dan rohaniahnya dengan sifat-sifat sabar, bertanggungjawab, adil, jujur, pemaaf dan kesemua sifat tersebut mesti tercermin dalam pribadi guru. Dengan demikian keteledanan guru dilakukan dalam upaya menghilangkan dan mengikis sifat-sifat buruk yang akan melekat pada diri siswa seperti iri hati, kikir, sombong, dengki dan sebagainya. Kedua : Faktor pendorong dalam pembinaan akhlak siswa adalah pemahaman agama siswa sudah mulai mendalam, sehingga penanaman nilai-nilai akhlak kepada mereka lebih mudah. Selain tiu didukung dengan lingkungan tempat berdomisili siswa yang kondusif, sehingga lebih mudah membentuk kepribadian siswa kepada akhlak mulia. Sedangkan faktor penghalang yang dihadapi oleh guru dalam pembinaan akhlak adalah masih rendahnya pemahaman keagamaan siswa dan faktor lingkungan.

Sarandalam penelitian ini Pertama: Pembinaan akhlak melalui pendekatan keteladanan merupakan salah satu sarana yang sangat efektif, maka untuk itu sangat perlu setiap guru perlu memperlihatkan contoh yang baik terhadap siswa. Kedua; Bentuk penyampaian materi akhlak dalam pembelajaran di sekolah, diharapkan tidak hanya teori semata, akan tetapi dibutuhkan tindakan nyata oleh guru. Ketiga: Dalam pembinaan akhlak siswa di sekolah yang dilakukan oleh guru, perlu untuk bisa memilih metode yang tepat dan perlu didukung sarana dan prasarana pembelajaran yang memadai. Keempat: Dalam pembinaan akhlak siswa sangat diharapkan dukungan kepada masyarakat tetapi hendaknya masyarakat tidak terlalu ikut campur dalam pelaksanaan proses pembelajaran dan pembinaan akhlak yang dilakukan oleh guru. 


\section{DAFTAR PUSTAKAAN}

Ali Rajab, M. (1961). Taamulat fi Falfati al-Ahklak. Mesir: Maktabah Injalu.

Altar, H. (2014). Upaya Meningkatkan Disiplin Guru dalam Kehadiran Mengajar di Kelas Melalui Keteladanan Kepala Sekolah di SMP Negeri 5 Sengkang Kabupaten Wajo. Jurnal Bionature, 16-22.

Departemen Agama RI. (2003). Al-Qur'an dan Terjemahnya, Bandung: Diponegoro, tahun 2003, h. 241. Bandung: Diponegoro.

Departemen P \& K. (1988). Kamus Besar Bahasa Indonesia. Jakarta: Balai Pustaka.

Elsa Aprlianingsih, S. L. (2019). Hubungan Keteladanan Guru Terhadap Akhlak Siswa di MTs Ar-Rofiqy Kabupaten Bogor. Jurnal Mitra Pendidikan, 3(4), 541-552.

Irfan. (2019). Peran Keteladanan Guru Sosiologi dalam Membentuk Karakter Sosial Siswa di SMAN 1 Sape. EduSociata Jurnal Pendidikan Sosiologi, II(Ii), 8-16.

Iswandi. (2018a). Eksistensi Surau sebagai Lembaga Pendidikan Islam (Studi di Kampung Koto Pulai Kenagarian Kambang Kecamatan Lenganyang Pesisir Selatan). Menata Jurnal Manajemen Pendidikan Islam, I(1), 1-32.

Iswandi. (2018b). Penerapan Metode Jibril dalam Meningkatkan Hafalan Siswa Kelas VII SMP DR. H. Abdullah Ahmad PGAI Padang. Vicratina Jurnal Pendidikan Islam, 3 Nomor 2, 37-53.

Kabiba, Pahenra, B. J. (2017). Keteladanan Orangtua dalam Menanamkan Nilai Etika pada Anak. Didaktis : Jurnal Pendidikan Dan Ilmu Pengetahuan, 17(1), 11-22.

Khairuni, N., \& Khairuni, N. (2016). Dampak Positif Dan Negatif Sosial Media Terhadap Pendidikan Akhlak Anak (Studi Kasus di SMP Negeri 2 Kelas VIII Banda Aceh). JURNAL EDUKASI: Jurnal Bimbingan Konseling, 2(1), 91-106. https://doi.org/10.22373/je.v2i1.693

Kirom, A. (2017). Peran guru dan peserta didik dalam proses pembelajaran berbasis multikultural. Al Murabbi: Jurnal Pendidikan Agama Islam, 3(1), 69-80. Retrieved from http://jurnal.yudharta.ac.id/v2/index.php/pai/article/view/893

Li'ah Haryati. (2016). Upaya Meningkatkan Disiplin Guru dalam Kehadiran Mengajar adi Kelas Melalui Penerapan Reward and Funishment. Media Didaktika, 2(2), 191-200. https://doi.org/10.33578/pjr.v3i3.7117 
Nurchaili. (2010). Membentuk Karakter Siswa Melalui Keteladanan Guru. Jurnal Pendidikan Dan Kebudayaan, 16(9), 233. https://doi.org/10.24832/jpnk.v16i9.515 Penulis. (n.d.). Observasi di MIN Bandar Gadang.

Putra, A. R. B. (2015). Peran Guru Bimbingan Dan Konseling Dalam Mengatasi Kecenderungan Perilaku Agresif Peserta Didik Di Smkn 2 Palangka Raya Tahun Pelajaran 2014/2015. Jurnal Konseling Gusjigang, 1(2). https://doi.org/10.24176/jkg.v1i2.406

Rahendra Maya. (2016). Revitalisasi Keteladanan dalam Pendidikan Islam. Edukasi Islam Jurnal Pendidikan Islam, 05, 1175-1183.

Rahmat Rais, Mudzanatun, M. R. S. (2012). Pengaruh Sikap Guru dalam Pembentukan Akhlak Mulia Melalui Keteladanan Guru di SDN Ngaluran 2 Karanganyar Kabupaten Demak. Jurnal Upgris, 2(1), 37-44.

Ramayulis. (2002). Ilmu Pendidikan Islam. Jakarta: kalam Mulia.

Ratnawati. (2018). Prosiding Seminar Nasional Pendidikan Peranan Guru Sebagai Model Dalam Pembentukan Karakter Peserta Didik. Jurnal STKIP Andi Matappa, 1-11. Retrieved from https://journal.uny.ac.id/index.php/cp/article/view/7409/pdf Sabar Budi Raharjo. (2010). Pendidikan Karakter sebagai Upaya Mencipatakan Akhlak Mulia. Jurnal Pendidikan Dan Kebudayaan, 16(3), 229-238.

Salik, M. (2015). Mengembangkan Fitrah Anak Melalui Pendidikan Islam (Studi atas Pemikiran Hamka). El-QUDWAH, O(0), 1-11.

Santi, L. A. (n.d.). Guru MIN Bandar Gadang Wawancara. Padang.

Saripah, I. (2016). Peran Orang Tua Dan Keteladanan Guru Dalam. Jurnal Ilmiah Pendidikan, 10(2), 19-32. Retrieved from https://journal.uny.ac.id/index.php/cp/article/view/7409/pdf

Suhendri. (n.d.). Kepala MIN Bandar Gadang, Wawancara. Padang.

Sujiantari, N. K. (2016). Pengaruh Reward dan Punishment terhadap Motivasi Belajar Siswa dalam Pembelajaran IPS. Jurnal Jurusan Pendidikan Ekonomi, 7(2), 1-10.

Suryadarma, Y., \& Haq, A. H. (2015). Pendidikan Akhlak Menurut Imam Al-Ghazali. Jurnal At-Ta'dib, 10(2), 362-381.

Taklimudin. (2018). Metode Keteladanan Pendidikan Islam dalam Persfektif Quran. Metode Keteladanan Pendidikan Islam Dan Persfektif Qur'an, 3(1), 1-22. https://doi.org/10.29240/bjpi.v3i1.383 